Volume 13

Issue 2 Rethinking Genocide, Mass Atrocities,

and Political Violence in Africa: New Directions,

Article 16

New Inquiries, and Global Perspectives

6-2019

\title{
Book Review: The Justice Façade: The Trials of Transition in Cambodia
}

Sabah Carrim

University of Malaya

Follow this and additional works at: https://digitalcommons.usf.edu/gsp

\section{Recommended Citation}

Carrim, Sabah (2019) "Book Review: The Justice Façade: The Trials of Transition in Cambodia," Genocide Studies and Prevention: An International Journal: Vol. 13: Iss. 2: 155-158.

DOI:

https://doi.org/10.5038/1911-9933.13.2.1653

Available at: https://digitalcommons.usf.edu/gsp/vol13/iss2/16

This Book Review is brought to you for free and open access by the Open Access Journals at Digital Commons @ University of South Florida. It has been accepted for inclusion in Genocide Studies and Prevention: An International Journal by an authorized editor of Digital Commons @ University of South Florida. For more information, please contact digitalcommons@usf.edu. 


\title{
Book Review: The Justice Façade: The Trials of Transition in Cambodia
}

\author{
Sabah Carrim \\ University of Malaya \\ Kuala Lumpur, Malaysia
}

The Justice Façade: The Trials of Transition in Cambodia

Alexander Laban Hinton

Oxford, Oxford University Press, 2018

304 pages; £24.99 Paperback

Reviewed by Sabah Carrim

Department of International and Strategic Studies, University of Malaya

"Everything that's important goes on in the darkness, no doubt about it," said Céline, author of Journey to the End of the Night, alluding to the vortex of one's psyche where the most important thoughts are formed, and decisions made. Alexander Hinton's The Justice Facade is also a book that sheds light on what's important but obscured, this time by the grand aims of Transitional Justice (TJ).

Written as a complement, rather than a rejoinder to Kathryn Sikkink's The Justice Cascade, ${ }^{1}$ The Justice Facade brings to the fore an important and timely debate on the Greek concept of "telos". This term, which signifies "the ultimate object or aim", has long dominated the way we think, and also defined the way we present and evaluate information. In essence, the prevalence of this idea in everything we do, implies that after objectives have been set down, our focus is shifted entirely on whether, and how far these have been achieved, denoting our obsession with causal effects. It also demonstrates the superstitious belief on our part in radical changes, linear in nature, from a "Before" to an "After", 2 say from primitiveness to modernity, or authoritarian rule to a democracy, when in truth, the transformations may be more dispersed, interstitial, and rhizomic, giving credence to "variance and complexity". ${ }^{3}$ The problem with understanding change in terms of such linearity is that considerations of all collateral effects-good and bad-are foregone, so that for the most part, our critical appraisal of the project or endeavour in question, ends up being reductive and inadequate. Along similar lines, Hinton draws our attention to the idealism inherent in the causal aims of TJ, these being articulated as "justice, national reconciliation, stability, peace, and security" ${ }^{\prime \prime}$, and then turns our attention to all that happens insidiously, surreptitiously and organically when a tribunal is set up, focusing on the study of the Extraordinary Chambers in the Courts of Cambodia (ECCC). This tribunal, he reveals, paved the way for alternative modes of peace, justice and reconciliation to be instilled among survivors and their families, in ways as simple as "the ability to forget the past, to share coffee or tea with neighbours who were once enemies, or to rebalance one's relationships to the spirits of the dead." ${ }^{5}$ Therefore, beyond the traditional discourse on TJ and whether its aims have been achieved, the lighting of incense sticks, the holding of prayers and incantations, and the performance of cremation ceremonies, ${ }^{6}$ should also be looked upon as attempts to instill peace, justice and reconciliation. They are after all attempts to reconnect with the dead, the tortured, and finally soothe angry and wandering souls, and "restore the equilibrium", all this against the backdrop of a predominantly Buddhist society.

But in this exercise of salvaging information which is usually discarded (or redacted), the information that Hinton restores to us is (not surprisingly) not entirely positive, in that it does not

\footnotetext{
${ }^{1}$ Kathryn Sikkink, The Justice Cascade - How Human Rights Prosecutions Are Changing World Politics (New York: W. W. Norton \& Company, 2011).

${ }^{2}$ Alexander Laban Hinton, The Justice Facade - Trials of Transition in Cambodia (Oxford: Oxford University Press, 2018 ), 16.

${ }^{3}$ Michael Vickery, Cambodia 1975-1982, 2nd ed. (Chiang Mai: Silkworm Books, 1999).

${ }^{4}$ Hinton, The Justice Façade, 3.

${ }^{5}$ Ibid., 7.

${ }^{6}$ Ibid., 93.
}

Sabah Carrim. "Book Review: The Justice Façade: The Trials of Transition in Cambodia" 13, 2 (2019): 155-158. @2019 Genocide Studies and Prevention. 
necessarily paint a rosy picture of the peace, justice and reconciliation that have been restored in Cambodia through the presence of TJ mechanisms such as the ECCC. There are also drawbacks of this attempt to meddle with the country's past. For instance, Hinton highlights the extent of "variation" among survivors who didn't all wish for, or believe in legal accountability to alleviate their suffering, preferring instead to leave things be in their own manner of making peace with the past. ${ }^{7}$ Others, favouring a policy of non-interference, relied on the Buddhist belief of reincarnation to restore the balance of good and evil that had been upset. ${ }^{8}$ The ECCC also purportedly camouflaged the existing inequalitiy in society, and unduly empowered the Cambodian People's Party(CPP). ${ }^{9}$ It is equally noteworthy that the ECCC's presence in the country posed somewhat a threat to those who had already been schooled in Western thinking - hence, Hinton recounts the dissonance that survivors such as Theary Seng experienced, in trying to reconcile more "passive" Buddhist beliefs with the western values that she had been imbibed in..$^{10}$ As far as victim expressivism or participation was concerned, although many promises were made initially, especially with the ECCC being the first international tribunal of its genre to encourage it, many, including Theary Seng, were met with disappointment, as they ended up being denied the right to voice out their suffering. ${ }^{11}$ Furthermore, those who had connections with victims of S-21, felt doubly injured by Duch's final testimony at the ECCC, where at the end of his defence, he sought to deny responsibility for the crimes he had committed on those premises, despite having initially provided all the evidence necessary to establish his guilt. ${ }^{12}$

One of the strengths of Hinton's The Justice Facade is that he goes beyond focusing on what happened through the set up of the ECCC, thereby depoliticising an event which many would misleadingly consider to have been the one and only attempt at transforming Cambodia from the rule of authoritarianism to a liberal democracy. Hinton thus explores how Khmer Rouge survivors achieved some of the ideals of TJ in the pre-ECCC years, as well as outside the ambit of the court setting after it was set up in 2007. For the former, he identifies three transitions: the first being the period when the PRK (People's Republic of Kampuchea) took over command of Cambodia after the rule of the Khmer Rouge and acknowledged the atrocities committed by the Pol Pot regime; the second through the People's Revolutionary Tribunal in 1979 which provided a forum of catharsis for survivors who testified to the suffering they had endured; and the third when the UNTAC established itself in Cambodia in the early 1990s and engaged in democratisation efforts. ${ }^{13}$ Hinton illustrates how the presence of this international organisation in the country transformed how the Khmer Rouge atrocity was referred to by the people, from it being referred to by the euphemistic "the policies and practices of the past" to the actual terminology it merited: a genocide. ${ }^{14}$ This in itself was an indicator of some sort of coming to terms with what had happened.

As mentioned earlier, Hinton also details the more informal forms of justice that occurred outside or beyond the premises of the ECCC, albeit triggered by its presence in the country. Thus he explains how Reach Sambath, a survivor, worked for the ECCC, where memories of the atrocities were conjured up, often depriving him of sleep, and how by continuing work at the court, it made him feel that he was acting on behalf of the victims of the Khmer Rouge. ${ }^{15}$ Other factors also contributed to process of reforming a country suffering from the aftermaths of a war: Lao Mong Hay for example, who had lived in England during the Khmer Rouge atrocities, was to return to his native country many years later and through the "transfer of technology", adopt some of the practices and values of the more developed country he had been exposed to, introducing a

\footnotetext{
${ }^{7}$ Ibid., 82.

${ }^{8}$ Ibid., 82-83.

${ }^{9}$ Ibid., 92-93.

${ }^{10}$ Ibid., 101-04.

${ }^{11}$ Ibid., 27.

${ }^{12}$ Ibid., 129-130.

${ }^{13}$ Ibid., 44-48.

${ }^{14}$ Ibid., 50 .

${ }^{15}$ Ibid., 150.
} 
Proto-Ombudsman Program, among other things. ${ }^{16}$ Nou Va, a KID (Khmer Institute of Democracy) staffer, who was a law graduate with a passion for human rights was included in a program for outreach, and in turn, had an important influence on other young jurists training them in "Western notions of law, human rights, and critical thinking." ${ }^{17}$ At a more simple day-to-day level, Hinton also discusses strategies adopted by Cambodians to deal with the past, such as using tiger balm, "coining", "cupping", visiting monks and other persons revered by Cambodian society, or merely discussing the past with friends and relatives. ${ }^{18}$ Hinton also recounts how another survivor, Vannah Cheah burnt incense and performed prayers in dealing with the howling of dogs-a bad omenon premises where the skeletons of two babies had been found..$^{19}$ These examples reveal the modest but important influences of NGOs on the overall process of establishing TJ ideals. Furthermore, at a more individual level, Hinton illustrates the details of Theary Seng's life journey, where as a Khmer Rouge survivor, then later a Christian convert living as an immigrant in Southern Carolina, she experienced rehabiliation by finding peace in a foreign country and religion (Christianity). ${ }^{20}$ Moreover Hinton avers that in Cambodia, both Buddhist and Muslim(Cham) beliefs had long before the ECCC initiated the process of making peace with the past. ${ }^{21}$ Another key survivor, Vann Nath who was known as the Goya of Cambodia, found meaning in painting vivid scenes of the torture meted out during the Khmer Rouge-this means of expression, was where he sought and found relief. ${ }^{22}$ These are some of the traditional or informal means of achieving peace that are almost always absent from mainstream discourses on the rehabilitation of society.

Hinton also explains how ECCC's influence on justice is also correlated with ECCC's personal jurisdictional limitations. So for example, by restricting the evaluation of guilt to the atrocities that occurred between April 17, 1975 and January 6, 1979, the tribunal sought justice only for perpetrations that happened in this period. Hinton criticises this as being a limited understanding of the plight of Cambodians, as it overlooks the greater picture of Cambodia's history of struggle, and the injustices that occurred even in the aftermath of the Khmer Rouge's fall. ${ }^{23}$ Thus Hinton also illustrates how Thun Saray, in the aftermath of the PRK's coming to power, in 1989, was imprisoned and tortured, and oustide of the mainstream discourse on relief through TJ, he managed to come to terms with what happened by setting up the first human rights NGO in Cambodia. ${ }^{24}$

\section{Method}

All the examples illustrated above, which only partially reveal the breadth and depth of Hinton's actual study, testify to all other forms of justice that are sought and sometimes achieved, but which do not figure in the main discourses assessing whether the grand aims of TJ were met. True to his method of reintroducing that which is normally erased, edited out or redacted, The Justice Facade is one more proof of the importance of exercising caution when relegating information that does not suit our main agenda.

On deeper thought, dialectical writing and thinking, or that which forms the basis of academic exercise, is often (and rather disappointingly) about justifying pre-decided conclusions by using rationalisms or rules of logic. This implies that a lot of valuable information which does not fit "the agenda" is inevitably devalued. Hinton's modus operandi so far has been to recycle all the discarded information and restore it to its rightful status by including it within the discourse it ought to belong to. It is tempting to perceive this rather novel methodology as having seriously put into question the long-held claims of academia as being a scientific, rational, dispassionate

\footnotetext{
${ }^{16}$ Ibid., 66-70.

${ }^{17}$ Ibid., 74 .

${ }^{18}$ Ibid., 85.

${ }^{19}$ Ibid., 94 .

${ }^{20}$ Ibid., 90-91.

${ }^{21}$ Ibid., 114.

${ }^{22}$ Ibid., 140.

${ }^{23}$ Ibid., 38.

${ }^{24}$ Ibid., 52.
} 
and objective enterprise, as Hinton's methodology serves to perceive all information and input, as having traversed through politically charged filters, and hence suffering from bias. 